\title{
Carbon Dioxide Sequestration Capability of the Botanical Garden of Rome: Environmental and Economic Benefits
}

\author{
Loretta Gratani*, Rosangela Catoni, Flavio Tarquini \\ Department of Environmental Biology, Sapienza University of Rome, Rome, Italy \\ Email: *loretta.gratani@uniromal.it
}

How to cite this paper: Gratani, L., Catoni, R. and Tarquini, F. (2019) Carbon Dioxide Sequestration Capability of the Botanical Garden of Rome: Environmental and Economic Benefits. American Journal of Plant Sciences, 10, 1249-1260.

https://doi.org/10.4236/ajps.2019.108090

Received: June 21, 2019

Accepted: August 6, 2019

Published: August 9, 2019

Copyright () 2019 by author(s) and Scientific Research Publishing Inc. This work is licensed under the Creative Commons Attribution International License (CC BY 4.0).

http://creativecommons.org/licenses/by/4.0/

\begin{abstract}
Carbon dioxide $\left(\mathrm{CO}_{2}\right)$ is one of the most abundant anthropogenic greenhouse gases contributing to increase air temperature. Urban areas covered by parks, gardens, tree-lined avenues, sports fields, and hedges are important sinks for $\mathrm{CO}_{2}$. Urban green areas should include the Botanical Gardens, taking into consideration their key role in ex situ plant conservation as well as air quality amelioration and social benefits. In such context, the $\mathrm{CO}_{2}$ sequestration capability of the most representative plant collections developing in the Botanical Garden of Rome and their influence on microclimate was analyzed. Our results highlight that plant collections have a $\mathrm{CO}_{2}$ sequestration capability of $6947 \mathrm{Mg} \mathrm{CO}_{2}$ year $^{-1}$. The $\mathrm{CO}_{2}$ sequestration capability and air temperature lowering by plant collections growing in the Botanical Garden have positive effects $(\mathrm{p} \leq 0.05)$ on the surrounding area resulting in $4 \% \mathrm{CO}_{2}$ concentration and $1^{\circ} \mathrm{C}$ air temperature decreasing at $150 \mathrm{~m}$ from the centre of the Garden.
\end{abstract}

\section{Keywords}

Air Quality Amelioration, Plant Collections, Urban Greening

\section{Introduction}

Urban areas are rapidly expanding globally and it is expected that $60 \%$ of the world's population will be living in cities by 2030 [1]. Cities account for more than $70 \%$ of the energy-related to global greenhouse gases [2] [3] and carbon dioxide $\left(\mathrm{CO}_{2}\right)$ is one of the most abundant anthropogenic greenhouse gases contributing to increase air temperature [4]. The exchange of $\mathrm{CO}_{2}$ over cities is mostly governed by anthropogenic emissions originating from road traffic and local heating with natural gas, oil and coal [5]. As urbanization increases global- 
ly, it is becoming important to better clarify the carbon (C) dynamics of urban ecosystems [6]. European cities are sharing their knowledge of climate policy initiatives. In particular, London, Paris, Berlin, and Rome have signed the Covenant of Mayors including commitments to implement sustainable energy policies (e.g. increased energy efficiency and development of renewable energy sources) that meet and exceed the EU's $20 \% \mathrm{CO}_{2}$ emissions reduction objective. In addition to the energy efficiency and renewable energy sources, $\mathrm{CO}_{2}$ emissions reduction can be achieved by plants [3]. Plants remove $\mathrm{CO}_{2}$ from the atmosphere through photosynthesis and storing the carbon excess as biomass in roots, stems, and branches [4]. Nevertheless, today the relationship between vegetated urban areas and $\mathrm{CO}_{2}$ emissions reduction has not been clarified and recently only the use of plants to ameliorate urban air quality has become a focus of research [7] [8]. In particular, urban areas covered by parks, gardens, tree-lined avenues, sports fields, and hedges are important sinks for $\mathrm{CO}_{2}[8]$. The $\mathrm{CO}_{2}$ sequestration capability is related to species, plant age and growing conditions [9]. Urban greening also contributes to decrease air temperature through shading, blocking wind and evapotranspiration, thus counteracting the urban heat island effects [10] and lowering building energy used for cooling [10]. Moreover, green spaces serve important social, psychological, health, aesthetic and ecological functions within urban areas [11]. When exposed to green areas, people show a greater well-being with physical and psychological benefits [12]. Among green areas, Botanical Gardens have a key role in plant conservation. The Botanic Gardens Conservation International (BGCI) defined Botanical Gardens as "Institutions holding documented collections of living plants for the purposes of scientific research, conservation, display and education" [13]. There are more than 1700 Botanical Gardens worldwide [14]. Europe has the highest number of Botanical Gardens (527): Germany (74), France (66), United Kingdom (61), Italy (48) and the Netherlands (39) [14]. Botanical Gardens have a significant role in plant ex situ conservation [15], taxonomic research [16], horticultural and economic Botany [17], public education and natural history appreciation [18]. Botanical Gardens also offer economic benefits associated with attracting tourists [19]. Some visitors appreciate the educational experiences and opportunities to view unusual or rare species, and others their role in maintaining local traditions and community identity [20]. In this context, we analyzed an additional role for the Botanical Gardens that should be considered, i.e. the contribution to environmental quality amelioration. In particular, the $\mathrm{CO}_{2}$ sequestration capability of the most representative plant collections developing in the Botanical Garden of Rome (Italy) and their influence on microclimate was analyzed.

\section{Methods}

\subsection{The Study Area}

The study was carried out in the period January-May 2016 inside the Botanical 
Garden of Rome ( $41^{\circ} 53^{\prime} 53^{\prime \prime} \mathrm{N}, 12^{\circ} 28^{\prime} 46^{\prime \prime}$ E; $53 \mathrm{~m}$ a.s.l.). The Botanical Garden covers an area of 12 ha in the city centre, between Lungara Street and the Gianicolo Hill. The plane area is enriched with tree species, the Palm Collection and meadows, while the hill area is occupied by Ferns, Eucalyptus collection, Bamboos, Rose Garden, Japanese Garden, Rock Garden and Geophytes, Mediterranean Wood and Gymnosperms [21].

The study area is under a Mediterranean type of climate. The average total annual rainfall is $848 \mathrm{~mm}$, most of it distributed in autumn and winter. The average maximum air temperature of the hottest months (July and August) is $31.7^{\circ} \mathrm{C} \pm 0.1^{\circ} \mathrm{C}$ and the average minimum air temperature of the coldest month (January) is $4.9^{\circ} \mathrm{C} \pm 0.9^{\circ} \mathrm{C}$. The mean yearly air temperature is $16.7^{\circ} \mathrm{C} \pm 6.5^{\circ} \mathrm{C}$ (data provided by the Lazio Regional Agency for Development and Agricultural Innovation; Meteorological Station of Rome, Lanciani Street, data for the period 2006 to 2016).

\subsection{Carbon Dioxide Concentration and Microclimate Measurement}

Atmospheric carbon dioxide concentration $\left(\mathrm{CO}_{2}, \mathrm{ppm}\right)$, air temperature $\left(\mathrm{T}_{\mathrm{a}},{ }^{\circ} \mathrm{C}\right)$ and air humidity (RH, \%) were monitored simultaneously by handheld tools (Rotronic, CP11) along two Transects: Transect 1 from Garibaldi Square to the centre of the Botanical Garden and Transect 2 from Lungotevere della Farnesina Street to the centre of the Botanical Garden. Measurements were carried out in three different points of each transect: at the centre of the Garden (C), at $150 \mathrm{~m}$ from the centre $\left(B_{1}\right.$ and $B_{2}$, for Transect 1 and 2, respectively) and outside the Botanical Garden (at $300 \mathrm{~m}$ from the centre, $A_{1}$ at Garibaldi Square and $A_{2}$ at Lungotevere della Farnesina, for Transect 1 and 2, respectively) (Figure 1). Traffic level (i.e. number of vehicles per minute) was monitored simultaneously with $\mathrm{CO}_{2}$ measurements in Garibaldi Square and Lungotevere della Farnesina Street. The sites along each transect were chosen on the base of a progressive traffic intensity decrease from street densely congested to the inner of the Botanical Garden.

\subsection{Plant Collections}

The most important plant collections developing in the Botanical Garden were considered. In particular, the Mediterranean Garden $\left(2050 \mathrm{~m}^{2}\right)$, Palms (4463 $\left.\mathrm{m}^{2}\right)$, Gymnosperms $\left(15,500 \mathrm{~m}^{2}\right)$, Bamboos $\left(6205 \mathrm{~m}^{2}\right)$, Mediterranean Wood $\left(17,850 \mathrm{~m}^{2}\right)$, Eucalyptus Collection $\left(8500 \mathrm{~m}^{2}\right)$, Japanese Garden $\left(2250 \mathrm{~m}^{2}\right)$, Erythrina Area $\left(13,005 \mathrm{~m}^{2}\right)$, Ferns $\left(4250 \mathrm{~m}^{2}\right)$, Rock Garden and Geophytes (5100 $\left.\mathrm{m}^{2}\right)$, Rose Garden $\left(4250 \mathrm{~m}^{2}\right)$ and Meadows $\left(2423 \mathrm{~m}^{2}\right)$ (Figure 2).

The extension of each plant collection was measured by a Quantum Gis (QGIS), an Open Source Geographic Information System (OSGEO4W, version 1.8.0) running on Windows. QGIS determines the acquisition, recording, analysis, visualization and restitution of information by geographical data. The GIS 


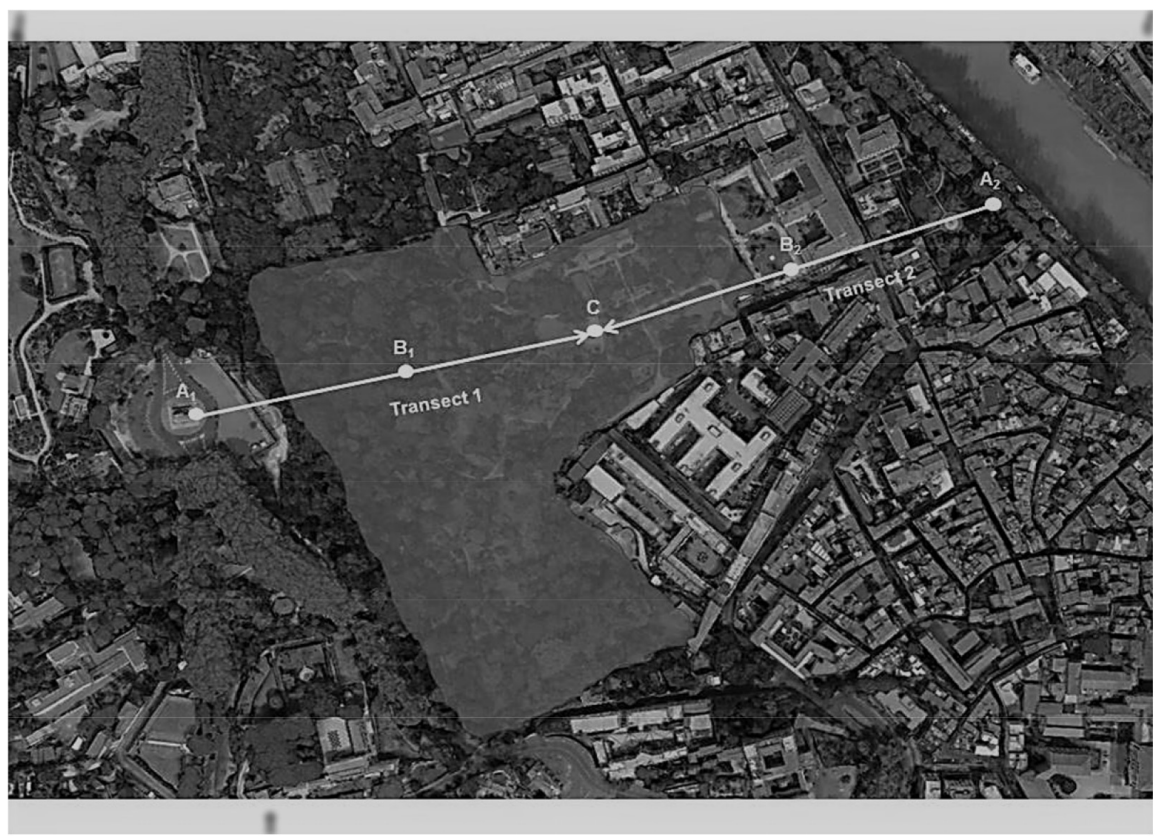

Figure 1. The two Transects monitored from the outside to the centre of the Botanical Garden of Rome $\left(41^{\circ} 53^{\prime} 53^{\prime \prime} \mathrm{N}, 12^{\circ} 28^{\prime} 46^{\prime \prime} \mathrm{E}\right.$ ). Transect 1: $\mathrm{A}_{1}$ (Garibaldi Square, at $300 \mathrm{~m}$ from the centre), $B_{1}$ (at $150 \mathrm{~m}$ from the centre), $C$ (centre of the Botanical Garden). Transect 2: $A_{2}$ (Lungotevere della Farnesina Street, at $300 \mathrm{~m}$ from the centre), $B_{2}$ (at 150 $\mathrm{m}$ from the centre), $\mathrm{C}$ (centre of the Botanical Garden).

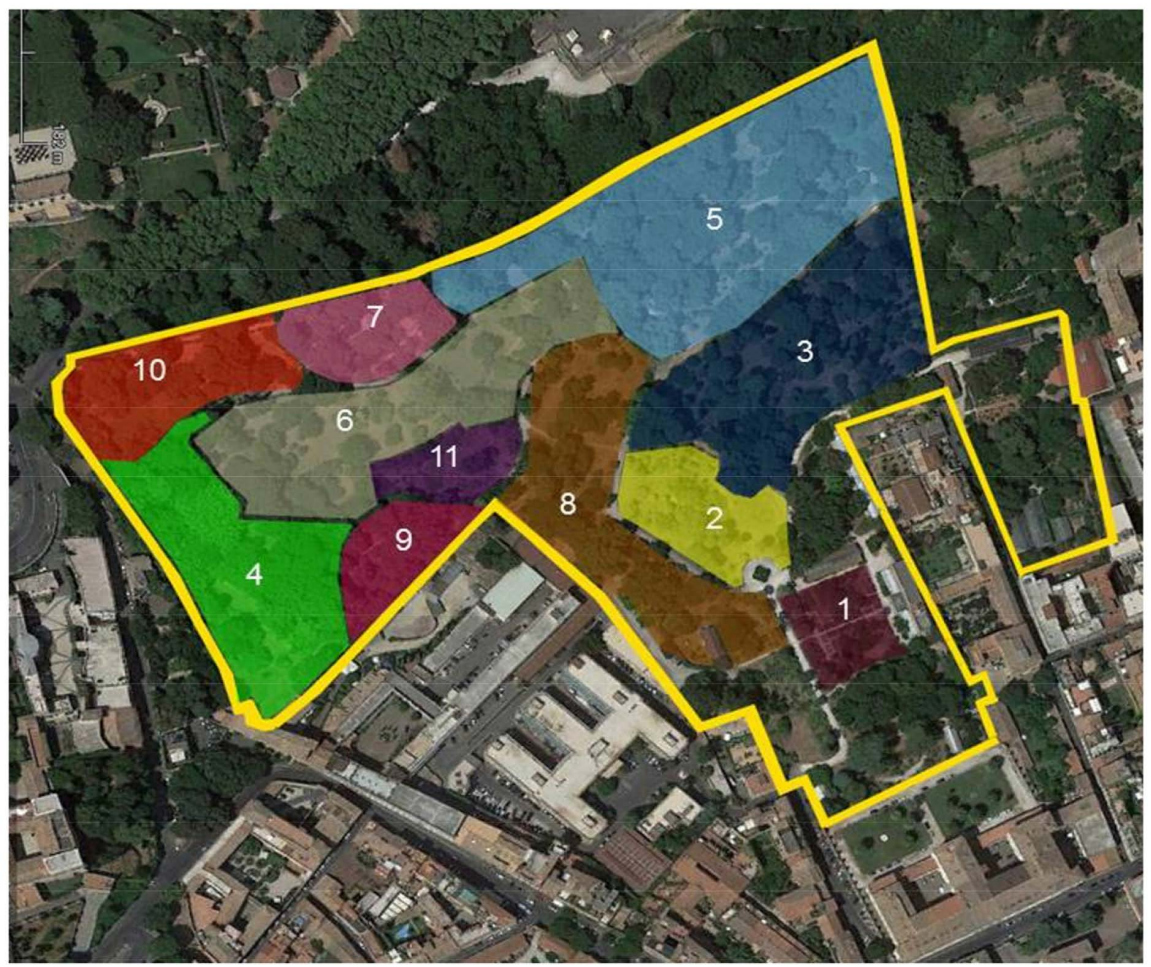

Figure 2. Map of the considered plant collections inside the Botanical Garden of Rome. 1 = Mediterranean Garden; 2 = Palms; 3 = Gymnosperms, 4 = Bamboos; 5 = Mediterranean Wood, 6 = Eucalyptus Collection; 7 = Japanese Garden; $8=$ Erythrina Area; $9=$ Ferns; $10=$ Rock Garden and Geophytes; 11 = Rose Garden. 
software is useful for the census of urban green areas by the analysis of digital cartographies.

\subsection{Plant Traits}

Leaf Area Index (LAI) was measured by the "LAI 2000 Plant Canopy Analyzer" (LICOR Inc., Lincoln, USA) for all the considered plant collections. Structural traits of each collection, excluding Meadows, were measured on representative plants ( $\mathrm{n}=10$ per plant collection). In particular, tree diameter at breast height $(\mathrm{DBH}, \mathrm{m})$ was measured by callipers (Silvanus calliper-65 cm), and a DBH tape (length $=20 \mathrm{~m}$ ) when diameter was larger than $65 \mathrm{~cm}$. Plant height $(\mathrm{H}, \mathrm{m})$ was measured by electronic clinometers (Haglöf, Sweden). The total photosynthetic leaf surface area (TPS, $\mathrm{m}^{2}$ ) of each plant collection was determined by multiplying each LAI value by the extension of the plant collection.

\subsection{Carbon Dioxide Sequestration}

The $\mathrm{CO}_{2}$ sequestration capability for each plant collection was calculated multiplying TPS by the mean yearly net photosynthesis and the total yearly photosynthetic activity time (in hours), according to [22]. In order to compare $\mathrm{CO}_{2}$ sequestration capability of the different plant collections, the $\mathrm{CO}_{2}$ sequestration capacity per hectare (CS, $\mathrm{Mg} \mathrm{CO}_{2} \mathrm{ha}^{-1} \cdot \mathrm{year}^{-1}$ ) was calculated. The total $\mathrm{CO}_{2}$ sequestration capacity of the Botanical Garden was also calculated $\left(\mathrm{CS}_{\mathrm{Tot}}\right)$.

The net photosynthetic rate $\left(N_{\mathrm{P}}, \mu \mathrm{mol} \cdot \mathrm{m}^{-2} \cdot \mathrm{s}^{-1}\right)$ was measured by an open infrared $\mathrm{CO}_{2}$ gas analyzer (ADC LCPro+, UK), equipped with a leaf chamber (PLC, Parkinson Leaf Chamber). Measurements were made in situ on cloud-free days (PAR $>1000 \mu \mathrm{mol} \cdot \mathrm{m}^{-2} \cdot \mathrm{s}^{-1}$ ), in the morning (from 9:00 am to 12:00 $\mathrm{pm}$ ), to ensure that near maximum daily $N_{\mathrm{P}}$ was measured. On each sampling occasion, fully sun expanded leaves were used (Varone et al., 2015). Leaves were retained in their natural position during measurements. Measurements were carried out at ambient air temperature on five representative plants per each collection (three leaves per plants).

\subsection{Monetary Value of $\mathrm{CO}_{2}$ Sequestration}

The monetary value of $\mathrm{CO}_{2}$ sequestration for the collections growing in the Botanical Garden was estimated assuming a monetary value of $\$ 0.00334 / \mathrm{lb}$ (i.e. $\$ 0.00736 / \mathrm{kg}$ ) for sequestered $\mathrm{CO}_{2}$, according to [23].

\subsection{Statistical Analysis}

Differences of the means were tested by one-way analysis of variance (ANOVA), and Tukey test for multiple comparisons. Moreover, in order to understand how LAI, TPS and $N_{\mathrm{P}}$ (predictors) affected CS (response variable), the predictors were combined via Principal Component Analysis (PCA) across plant collections. Then, a simple linear regression analysis between the axis explaining the largest proportion of the variance (i.e. $\mathrm{PC}_{1}$ ) and $\mathrm{CS}$ was carried out. All statistical 
tests were performed using a statistical software package (Statistica, Statsoft, USA).

\section{Results}

\subsection{Carbon Dioxide Concentration and Microclimate}

The mean $\mathrm{CO}_{2}$ concentration during the study period was $485 \pm 22 \mathrm{ppm}$ (mean value of Transect 1 and Transect 2) peaking in January (522 $\pm 21 \mathrm{ppm}$, mean of $\mathrm{A}_{1}$ and $\mathrm{A}_{2}$ ) (Table 1). The highest $\mathrm{CO}_{2}$ concentration was monitored where the traffic level was the highest ( $31 \pm 1$ vehicles.min ${ }^{-1}$, mean of $A_{1}$ and $A_{2}$ ) decreasing by $8 \%$ in May (mean of $A_{1}$ and $A_{2}$ ) associated to a $21 \%$ decrease of the traffic level (mean of $A_{1}$ and $A_{2}$ ). Along the Transect $1, A_{1}$ had a $6 \%$ lower $\mathrm{CO}_{2}$ concentration compared to $\mathrm{A}_{2}$ (Transect 2) with a $70 \%$ lower traffic level. Moreover, $\mathrm{CO}_{2}$ concentration decreased, on average, $9 \%$ from outside to the centre of the Botanical Garden in both the Transects. In particular, $\mathrm{CO}_{2}$ concentration decreased $2 \%$ and $6 \%$ from $A_{1}$ to $B_{1}$ and from $A_{1}$ to $C$, respectively, along Transect 1 , and $6 \%$ and $12 \%$ from $A_{2}$ to $B_{2}$ and from $A_{2}$ to $C$, respectively, along Transect 2 .

A similar trend was observed in $\mathrm{T}_{\mathrm{a}}$ decreasing, on average, $14 \%$ from the outside to the centre of the Botanical Garden. In particular, $\mathrm{T}_{\mathrm{a}}$ decreased $7 \%$ and $13 \%$ from $A_{1}$ to $B_{1}$ and from $A_{1}$ to $C$, respectively, along Transect 1 , and $8 \%$ and $14 \%$ from $A_{2}$ to $B_{2}$ and from $A_{2}$ to $C$, respectively, along Transect 2 . An opposite trend was observed for $\mathrm{RH}$, increasing, on average, $7 \%$ from outside to inside the Botanical Garden (Table 1).

\subsection{Plant Traits}

Structural traits of plant collections are shown in Figures 3(a)-(d). The highest LAI ( $\mathrm{p} \leq 0.05)$ was measured in Bamboos $(2.90 \pm 0.06)$ and the lowest in Meadows $(0.40 \pm 0.05$, mean value). The Mediterranean Wood had the highest ( $\mathrm{p} \leq$ $0.05)$ TPS $\left(43,197 \mathrm{~m}^{2}\right)$ and the Meadows the lowest $\left(969 \mathrm{~m}^{2}\right)$. DBH was the highest $(\mathrm{p} \leq 0.05)$ in the Gymnosperms $(1.16 \pm 0.30 \mathrm{~m})$ and the lowest in Rose Garden $(0.06 \pm 0.03 \mathrm{~m})$. The Eucalyptus Collection had the highest $(\mathrm{p} \leq 0.05) \mathrm{H}$ $(26.8 \pm 2.3 \mathrm{~m})$.

\subsection{Carbon Dioxide Sequestration}

Bamboos had the highest CS $\left(210 \mathrm{Mg} \mathrm{CO}_{2} \mathrm{ha}^{-1} \cdot \mathrm{year}^{-1}\right.$, corresponding to $57.4 \mathrm{Mg}$ $\mathrm{C} \mathrm{ha}^{-1} \cdot \mathrm{year}^{-1}$ ) among plant collections, followed by the Mediterranean Wood (133 Mg CO $\mathrm{ha}^{-1} \cdot \mathrm{year}^{-1}$, corresponding to $36 \mathrm{Mg} \mathrm{C} \mathrm{ha}^{-1} \cdot \mathrm{year}^{-1}$ ) while Ferns had the lowest CS $\left(7.1 \mathrm{Mg} \mathrm{CO}_{2} \mathrm{ha}^{-1} \cdot \mathrm{year}^{-1}\right.$, corresponding to $\left.1.9 \mathrm{Mg} \mathrm{C} \mathrm{ha}^{-1} \cdot \mathrm{year}^{-1}\right)$ (Figure 4). Considering the extension of each plant collection, the Mediterranean Wood had the highest $\mathrm{CO}_{2}$ sequestration capability $\left(150 \mathrm{Mg} \mathrm{CO}_{2}\right.$ year $^{-1}$, corresponding to $65 \mathrm{Mg} \mathrm{C}$ year $\left.^{-1}\right)$, followed by the Bamboos (130 $\mathrm{Mg} \mathrm{CO}_{2}$ year $^{-1}$, corresponding to $36 \mathrm{Mg} \mathrm{C}$ year $\left.^{-1}\right)$, the Erythrina Area $\left(110 \mathrm{Mg} \mathrm{CO}_{2}\right.$ year $^{-1}$, corresponding to $30 \mathrm{Mg} \mathrm{CO}_{2}$ year $^{-1}$ ), Gymnosperms (109 $\mathrm{Mg} \mathrm{CO}_{2}$ year $^{-1}$, 
Table 1. Carbon dioxide concentration $\left(\mathrm{CO}_{2}\right)$, air temperature $\left(T_{\mathrm{a}}\right)$ and air humidity $(\mathrm{RH})$ monitored during the study period (January-May) along the two Transect from the outside to the centre of the Botanical Garden of Rome. Transect 1: $\mathrm{A}_{1}$ (Garibaldi Square, at $300 \mathrm{~m}$ from the centre), $B_{1}$ (at $150 \mathrm{~m}$ from the centre), $C$ (centre of the Botanical Garden). Transect 2: $A_{2}$ (Lungotevere della Farnesina Street, at $300 \mathrm{~m}$ from the centre), $B_{2}$ (at $150 \mathrm{~m}$ from the centre), $C$ (centre of the Botanical Garden). Mean values for each point during the study period are indicated in bold. The differences between the three points of each Transect were always significant at $\mathrm{p} \leq 0.05$.

\begin{tabular}{|c|c|c|c|c|c|c|c|c|c|}
\hline & \multicolumn{3}{|c|}{$\mathrm{CO}_{2}(\mathrm{ppm})$} & \multicolumn{3}{|c|}{$\mathrm{T}_{\mathrm{a}}\left({ }^{\circ} \mathrm{C}\right)$} & \multicolumn{3}{|c|}{ RH (\%) } \\
\hline & \multicolumn{9}{|c|}{ Transect 1} \\
\hline Month & $\mathrm{A}_{1}$ & $\mathrm{~B}_{1}$ & C & $\mathrm{A}_{1}$ & $\mathrm{~B}_{1}$ & $\mathrm{C}$ & $\mathrm{A}_{1}$ & $\mathrm{~B}_{1}$ & $\mathrm{C}$ \\
\hline Jan & $507 \pm 1$ & $491 \pm 4$ & $474 \pm 1$ & $6.1 \pm 0.1$ & $5.9 \pm 0.1$ & $5.3 \pm 0.1$ & $72.5 \pm 0.9$ & $73.2 \pm 0.3$ & $76.4 \pm 0.4$ \\
\hline $\mathrm{Feb}$ & $502 \pm 2$ & $497 \pm 1$ & $479 \pm 2$ & $5.7 \pm 0.3$ & $4.9 \pm 0.1$ & $4.8 \pm 0.2$ & $71.2 \pm 0.8$ & $75.2 \pm 0.4$ & $78.5 \pm 0.4$ \\
\hline Mar & $502 \pm 1$ & $495 \pm 0.1$ & $489 \pm 2$ & $10.4 \pm 0.1$ & $10.3 \pm 0.1$ & $9.1 \pm 0.1$ & $70.0 \pm 0.1$ & $72.4 \pm 0.8$ & $77.4 \pm 0.5$ \\
\hline Apr & $463 \pm 2$ & $458 \pm 0.1$ & $427 \pm 1$ & $12.8 \pm \quad 0.5$ & $12.7 \pm 0.1$ & $12.5 \pm 0.1$ & $68.5 \pm 0.5$ & $70.2 \pm 0.6$ & $72.3 \pm 0.9$ \\
\hline \multirow[t]{4}{*}{ May } & $455 \pm 4$ & $444 \pm 1.2$ & $425 \pm 1$ & $22.4 \pm 0.1$ & $19.7 \pm 0.1$ & $18.4 \pm 0.1$ & $56.4 \pm 0.2$ & $60.2 \pm 0.8$ & $63.1 \pm 0.2$ \\
\hline & $486 \pm 25$ & $477 \pm 24$ & $459 \pm 30$ & $11.5 \pm 6.8$ & $10.7 \pm 6.0$ & $10.0 \pm 5.6$ & $67.7 \pm 6.5$ & $70.2 \pm 5.9$ & $73.5 \pm 6.3$ \\
\hline & \multicolumn{9}{|c|}{ Transect 2} \\
\hline & $\mathrm{A}_{2}$ & $\mathrm{~B}_{2}$ & $\mathrm{C}$ & $\mathrm{A}_{2}$ & $\mathrm{~B}_{2}$ & C & $\mathrm{A}_{2}$ & $\mathrm{~B}_{2}$ & $\mathrm{C}$ \\
\hline Jan & $536 \pm 6$ & $499 \pm 1$ & $474 \pm 0.9$ & $6.8 \pm 0.3$ & $6.7 \pm 0.1$ & $5.3 \pm 0.1$ & $74.5 \pm 0.3$ & $83.1 \pm 0.7$ & $76.4 \pm 0.4$ \\
\hline $\mathrm{Feb}$ & $529 \pm 1$ & $488 \pm 2$ & $479 \pm 2$ & $6.3 \pm 0.1$ & $5.8 \pm 0.2$ & $4.8 \pm 0.2$ & $75.4 \pm 0.1$ & $84.3 \pm 0.2$ & $78.5 \pm 0.4$ \\
\hline Mar & $514 \pm 2$ & $496 \pm 1$ & $489 \pm 2$ & $10.2 \pm 0.2$ & $8.6 \pm 0.1$ & $9.1 \pm 0.1$ & $74.6 \pm 0.3$ & $89.8 \pm 0.7$ & $77.4 \pm 0.5$ \\
\hline Apr & $510 \pm 3$ & $469 \pm 9$ & $427 \pm 1$ & $13.1 \pm 0.1$ & $13.0 \pm 0.6$ & $12.5 \pm 0.1$ & $69.1 \pm 0.1$ & $70.3 \pm 0.6$ & $72.3 \pm 0.9$ \\
\hline \multirow[t]{2}{*}{ May } & $508 \pm 2$ & $476 \pm 2$ & $425 \pm 1$ & $22.3 \pm 0.1$ & $19.7 \pm 0.1$ & $18.4 \pm 0.1$ & $53.3 \pm 0.5$ & $61.6 \pm 0.1$ & $63.1 \pm 0.2$ \\
\hline & $519 \pm 12$ & $486 \pm 13$ & $459 \pm 30$ & $11.7 \pm 6.5$ & $10.8 \pm 5.7$ & $10.0 \pm 5.6$ & $69.4 \pm 9.3$ & $77.8 \pm 11.5$ & $73.5 \pm 6.3$ \\
\hline
\end{tabular}

corresponding to $29 \mathrm{Mg} \mathrm{CO}_{2}$ year $\left.^{-1}\right)$, Eucalyptus Collection (35 $\mathrm{Mg} \mathrm{CO}_{2}$ year $^{-1}$, corresponding to $9 \mathrm{Mg} \mathrm{CO}_{2}$ year $\left.^{-1}\right)$, Palms $\left(28 \mathrm{Mg} \mathrm{CO}_{2}\right.$ year $^{-1}$, corresponding to $8 \mathrm{Mg} \mathrm{CO}_{2}$ year $\left.^{-1}\right)$, Mediterranean Garden $\left(17 \mathrm{Mg} \mathrm{CO}_{2}\right.$ year $^{-1}$, corresponding to 5 $\mathrm{Mg} \mathrm{CO}$ year $^{-1}$ ), Japanese Garden (15 $\mathrm{Mg} \mathrm{CO}_{2}$ year $^{-1}$, corresponding to $4 \mathrm{Mg}$ $\mathrm{CO}_{2}$ year $\left.^{-1}\right)$, Rose Garden, Rock Garden and Geophythes $\left(10.4 \pm 0.5 \mathrm{Mg} \mathrm{CO}_{2}\right.$ year $^{-1}$, mean value, corresponding to $2.8 \pm 0.1 \mathrm{Mg} \mathrm{CO}_{2}$ year $^{-1}$ ), Meadows (4.7 $\mathrm{Mg} \mathrm{CO}_{2}$ year ${ }^{-1}$ corresponding to $1.3 \mathrm{MgC}$ year $^{-1}$ ) and Ferns (3.0 $\mathrm{Mg} \mathrm{CO}_{2}$ year $^{-1}$, corresponding to $0.82 \mathrm{MgC}$ year $\left.^{-1}\right)$. Considering the total extension of plant collections (8.6 ha), the $\mathrm{CO}_{2}$ sequestration capability for the Botanical Garden was of $6947 \mathrm{Mg} \mathrm{CO}_{2}$ year $^{-1}$, corresponding to $1897 \mathrm{Mg} \mathrm{C}$ year $^{-1}$.

The PCA returned two axis of variations across plant collections. In particular, $\mathrm{PC}_{1}$ was positively related to LAI and TPS accounting for $55 \%$ of the total variance. $\mathrm{PC}_{2}$ was positively related to $N_{\mathrm{P}}$ accounting for $37 \%$ of the total variance. There was a significant linear regression between $\mathrm{PC}_{1}$ and CS. Nevertheless, the relationship did not hold for Gymnosperms and Bamboos collections which felt apart from the fitted line. When they were removed from the analysis, the performance of the linear model significantly increased (Figure 5). 


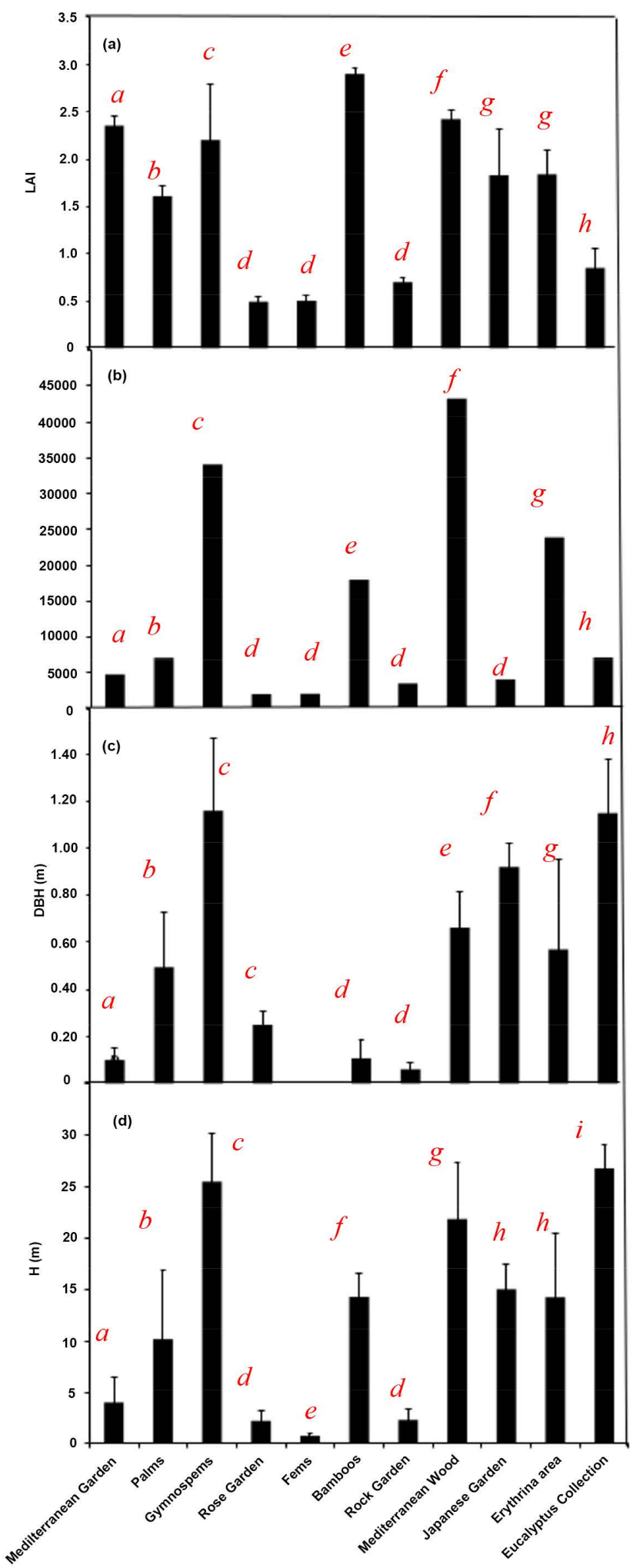

Figure 3. Leaf area index (LAI) (A), total photosynthetic leaf surface (TPS, $\left.\mathrm{m}^{2}\right)(\mathrm{B})$, diameter at the breast height $(\mathrm{DBH}, \mathrm{m})(\mathrm{C})$ and plant height $(\mathrm{H}, \mathrm{m})$ (D) of plant collections growing in the Botanical Garden of Rome. Mean values \pm S.E. are shown $(n=10)$. Mean values with the same letters are not significantly different $(\mathrm{p} \geq 0.05)$. 


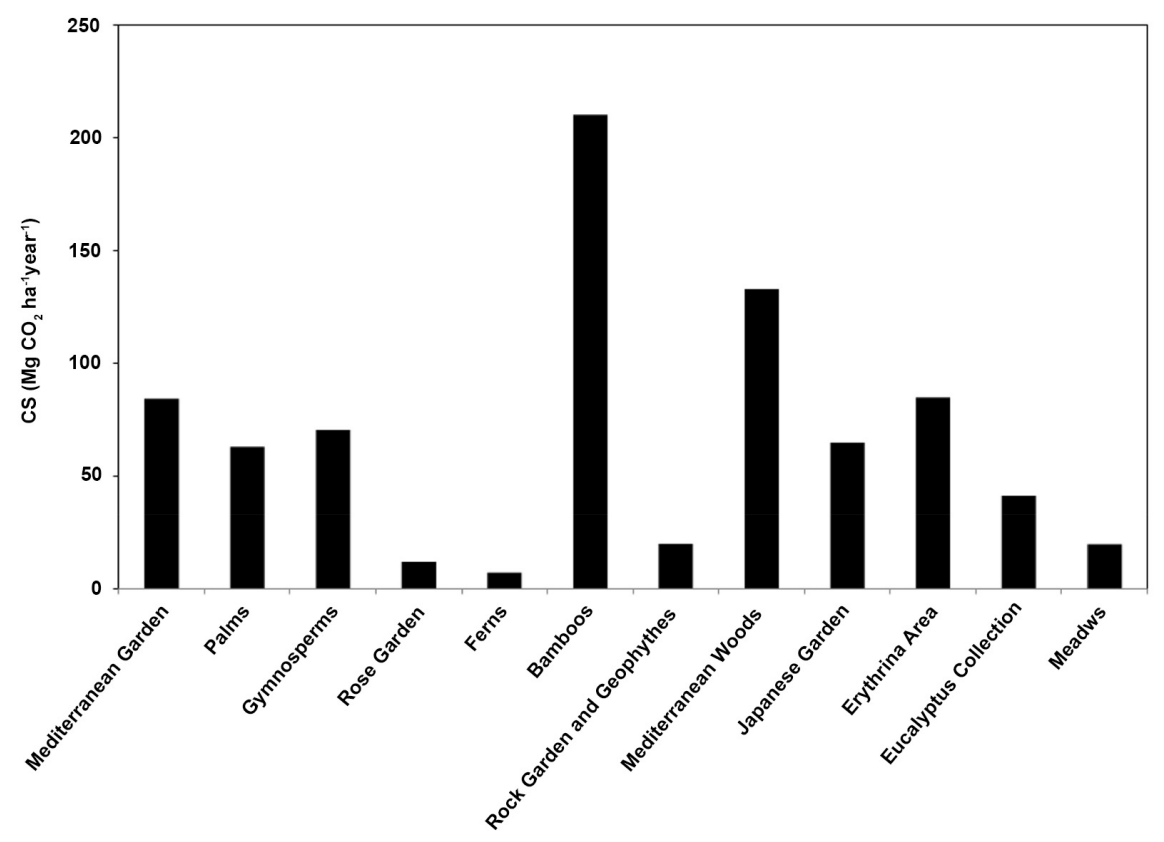

Figure 4. Carbon dioxide $\left(\mathrm{CO}_{2}\right)$ sequestration $\left(\mathrm{CS}, \mathrm{Mg} \mathrm{CO} \mathrm{Ca}^{-1} \cdot \mathrm{year}^{-1}\right)$ capability of the different plant collections growing in the Botanical Garden of Rome.

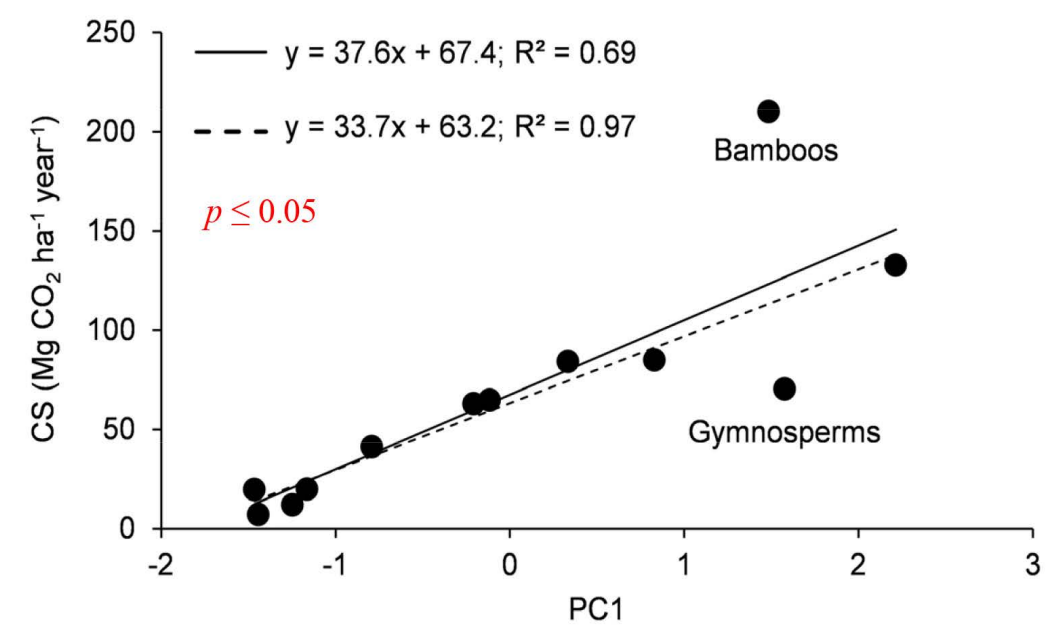

Figure 5. Linear relationship between the first principal component combining LAI and TPS (PC1) and the $\mathrm{CO}_{2}$ sequestration capacity per hectare (CS, $\mathrm{Mg} \mathrm{CO}$ $\mathrm{ha}^{-1} \cdot \mathrm{year}^{-1}$ ) across the Botanical Garden of Rome plant collections. The solid line represents the relationship obtained including all the plant collections $(n=12)$; the dashed line represents the same relationship by excluding Bamboos and Gymnosperms ( $n=8$; See Results section for further details). The equations, as well as their $\mathrm{R}^{2}$, are shown. The relationships were significant at $\mathrm{p} \leq 0.05$.

\subsection{Monetary Value of $\mathrm{CO}_{2}$ Sequestration}

The monetary value of $\mathrm{CO}_{2}$ sequestered by the Botanical Garden was 59$56 \$ \mathrm{ha}^{-1} \cdot \mathrm{year}^{-1}$, to which Bamboos and Mediterranean Wood gave the highest contribution (26\% and $16 \%$, respectively), and Ferns, Rose Garden (1\%) and Meadows (2\%) the lowest. 


\section{Discussion}

Quantifying $\mathrm{CO}_{2}$ sequestration by urban vegetation is necessary for the development of low-neutral carbon cities or climate-friendly cities [24]. Urban green areas should include the Botanical Gardens, taking into consideration their key role of ex situ plant conservation as well as air quality amelioration capability and social benefits. The city of Rome signing the Covenant of Mayors is committed to adopt an integrated approach to tackling climate change mitigation. Thus, a better awareness of the role of urban greening in $\mathrm{CO}_{2}$ reduction achieved should be included.

On the whole, our results show that plant collections inside the Botanical Garden of Rome cover 8.6 ha corresponding to $72 \%$ of the Botanical Garden extension (12 ha). The analyzed plant collections show different structural traits. In particular, Eucalyptus and Gymnosperm collections have the highest $\mathrm{H}$ and DBH $(26.2 \pm 0.9 \mathrm{~m}$ and $1.16 \pm 0.01 \mathrm{~m}$, respectively, mean value). LAI ranges from $2.90 \pm 0.06$ (Bamboos) to $0.40 \pm 0.05$ (Meadows). LAI is an important variable for characterizing vegetation structure and function [8]. It is related to photosynthesis and plant biomass [25]. The results show that structural traits are good predictors of plant collection $\mathrm{CO}_{2}$ sequestration capability as attested by the relationship between $\mathrm{PC}_{1}$ and CS. In particular, Gymnosperms have, on average, a lower CS $\left(70 \mathrm{Mg} \mathrm{CO} \mathrm{ha}^{-1} \cdot\right.$ year $^{-1}$ ) while Bamboos (210 $\mathrm{Mg} \mathrm{CO}_{2}$ $\mathrm{ha}^{-1} \cdot$ year $^{-1}$ ) a higher, than that predicted by the linear model. Nevertheless, the two collections show the same z-score on the obtained $\mathrm{PC}_{1}$ even if strongly differed in terms of CS. The same $\mathrm{z}$-score for these collections can be explained by TPS and LAI. Gymnosperms have 89\% higher TPS compared to Bamboos, with the latter being characterized by a $32 \%$ higher LAI. The high net photosynthetic rates of Bamboos [26] explain the divergence in CS compared to the other collections and the high contribution to $\mathrm{CS}_{\mathrm{Tot}}(26 \%)$. The lower CS of Gymnosperms compared to the other collections and the lower contribution to $\mathrm{CS}_{\mathrm{Tot}}$ (9\%) is linked to their low net photosynthetic rates [27]. Among the other collections, the Mediterranean Wood has the highest contribution to $\mathrm{CS}_{\text {Tot }}(16 \%)$, with a CS of $133 \mathrm{Mg} \mathrm{CO}_{2} \mathrm{ha}^{-1} \cdot$ year $^{-1}$. Moreover, the Mediterranean Garden and the Erythrina Area contribute $10 \%$ to $\mathrm{CS}_{\text {Tot }}$ with a CS of 84 and $85 \mathrm{Mg} \mathrm{CO}_{2}$ $\mathrm{ha}^{-1} \cdot$ year $^{-1}$, respectively. The Rose Garden and Ferns have the lowest CS, contributing less than $2 \%$ to $\mathrm{CS}_{\text {Tot }}$. Considering the extension of each collection, the Mediterranean Wood $\left(17,850 \mathrm{~m}^{2}\right)$ has the highest $\mathrm{CO}_{2}$ sequestration capability $\left(150 \mathrm{Mg} \mathrm{CO}_{2}\right.$ year $\left.^{-1}\right)$ while Ferns $\left(4250 \mathrm{~m}^{2}\right)$ the lowest $\left(3.0 \mathrm{Mg} \mathrm{CO}_{2}\right.$ year $\left.^{-1}\right)$. A total $\mathrm{CO}_{2}$ sequestration of $809 \mathrm{Mg} \mathrm{CO} \mathrm{ha}^{-1} \cdot \mathrm{year}^{-1}$ is obtained for the Botanical Garden of Rome, corresponding to $221 \mathrm{Mg} \mathrm{C} \mathrm{ha}{ }^{-1} \cdot \mathrm{year}^{-1}$. There is no comparative data since there have been no other studies on Botanical Gardens. This value is in the range of the most important historical parks in Rome [8]. The effects of $\mathrm{CO}_{2}$ sequestration of the plant collections growing inside the Botanical Garden results in $4 \% \mathrm{CO}_{2}$ reduction outside (150 m from the centre of the Botanical Garden). Moreover, plant collections decrease air temperature by $1^{\circ} \mathrm{C}$ inside the 
Botanical Garden with positive effects on the surrounding area.

Extending the $\mathrm{CS}_{\mathrm{Tot}}$ value for all the plant collections growing in the Botanical Garden of Rome, we obtain a total $\mathrm{CO}_{2}$ sequestration capability of $6947 \mathrm{Mg} \mathrm{CO}$ year $^{-1}$, corresponding to $1897 \mathrm{Mg} \mathrm{C}$ year $^{-1}$. This results in an annual economic value of $51,133 \$$. The obtained results can suggest appropriate policy interventions in order to facilitate future urban designs enhancing the environmental and social benefits from green areas that should also include Botanical Gardens.

\section{Conflicts of Interest}

The authors declare no conflicts of interest regarding the publication of this paper.

\section{References}

[1] Rydin, Y., Bleahu, A., Davies, M., Dávila, J.D., Friel, S., De Grandis, G., Groce, N., Hallal, P.C., Hamilton, I., Howden-Chapman, P., Lai, K.M., Lim, C.J., Martins, J., Osrin, D., Ridley, I., Scott, I., Taylor, M., Wilkinson, P. and Wilson, J. (2012) Shaping Cities for Health: Complexity and the Planning of Urban Environments in the 21st Century. The Lancet, 379, 2079-2108. https://doi.org/10.1016/S0140-6736(12)60435-8

[2] IEA (2008) World Energy Outlook: 2008. International Energy Agency, Paris.

[3] Russo, A., Escobedo, F.J., Timilsina, N. and Zerbe, S. (2015) Transportation Carbon Dioxide Emission Offsets by Public Urban Trees: A Case Study in Bolzano, Italy. Urban Forest and Urban Greening, 14, 398-403. https://doi.org/10.1016/j.ufug.2015.04.002

[4] Nowak, D.J. and Crane, D.E. (2002) Carbon Storage and Sequestration by Urban Trees in the USA. Environmental Pollution, 116, 381-389. https://doi.org/10.1016/S0269-7491(01)00214-7

[5] Kordowski, K. and Kuttler, W. (2010) Carbon Dioxide Fluxes over an Urban Park Area. Atmospheric Environment, 44, 2722-2730. https://doi.org/10.1016/j.atmosenv.2010.04.039

[6] Weissert, L.F., Salmond, J.A. and Schwendenmann, L. (2014) A Review of the Current Progress in Quantifying the Potential of Urban Forests to Mitigate Urban $\mathrm{CO}_{2}$ Emissions. Urban Climate, 8, 100-125. https://doi.org/10.1016/j.uclim.2014.01.002

[7] Yin, J., Yin, Z., Zhong, H., Xu, S., Hu, X., Wang, J. and Wu, J. (2011) Monitoring Urban Expansion and Land Use/Land Cover Changes of Shanghai Metropolitan Area during the Transitional Economy (1979-2009) in China. Environmental Monitoring and Assessment, 177, 609-621. https://doi.org/10.1007/s10661-010-1660-8

[8] Gratani, L., Varone, L. and Bonito, A. (2016) Carbon Sequestration of Four Urban Parks in Rome. Urban Forest and Urban Greening, 19, 184-193.

https://doi.org/10.1016/j.ufug.2016.07.007

[9] McPherson, E.G. (1998) Atmospheric Carbon Dioxide Reduction by Sacramento's Urban Forest. Journal of Arboriculture, 24, 215-223.

[10] Akbari, H., Pomerantz, M. and Taha, H. (2001) Cool Surfaces and Shade Trees to Reduce Energy Use and Improve Air Quality in Urban Areas. Solar Energy, 70, 295-310. https://doi.org/10.1016/S0038-092X(00)00089-X

[11] Tyrväinen, L., Pauleit, S., Seeland, K. and deVries, S. (2005) Benefits and Uses of Urban Forests and Trees. In: Konijnendijk, C.C., Nilsson, K., Randrup, T.P. and 
Schipper, J.N., Eds., Urban Forests and Trees, Springer, Heidelberg, 81-114. https://doi.org/10.1007/3-540-27684-X_5

[12] Saz-Salazar, S.D. and Rausell-Köster, P. (2008) A Double-Hurdle Model of Urban Green Areas Valuation: Dealing with Zero Responses. Landscape and Urban Planning, 84, 241-251. https://doi.org/10.1016/j.landurbplan.2007.08.008

[13] Wyse-Jackson, P.S. and Sutherland, L.A. (2000) International Agenda for Botanic Gardens in Conservation. Botanic Gardens Conservation International, London.

[14] UNEP (1995) Global Biodiversity Assessment. Cambridge University Press, Cambridge.

[15] Huang, H., Han, X., Kang, L., Raven, P., Jackson, P.W. and Chen, Y. (2002) Conserving Native Plants in China. Science, 297, 935-936. https://doi.org/10.1126/science.297.5583.935b

[16] Dosmann, M.S. (2006) Research in the Garden: Averting the Collections Crisis. Botanical Reviewer, 72, 207-234. https://doi.org/10.1663/0006-8101(2006)72[207:RITGAT]2.0.CO;2

[17] $\mathrm{Hu}, \mathrm{D}$. and Zhang, Z. (2008) The Role of Botanical Gardens in Horticultural Science. Acta Horticulture, 769, 493-496. https://doi.org/10.17660/ActaHortic.2008.769.71

[18] Maunder, M. (2008) Beyond the Greenhouse. Nature, 455, 596-597. https://doi.org/10.1038/455596a

[19] Sharpley, R. (2007) Flagship Attractions and Sustainable Rural Tourism Development: The Case of Alnwick Garden, England. Journal of Sustainable Tourism, 15, 125-143. https://doi.org/10.2167/jost604.0

[20] Kuzevanov, V.Y. and Sizykh, S.V. (2006) Botanic Gardens Resources: Tangible and Intangible Aspects of linking Biodiversity and Human Well-Being. Hiroshima Peace Science, 28, 113-134.

[21] Gratani, L. (2017) The Botanical Garden of Rome. Diano Libri srl, Palombi Editori, Modena (Italy).

[22] Gratani, L. and Varone, L. (2006) Carbon Sequestration by Quercus ilex L. and Quercus pubescens Willd. and Their Contribution to Decreasing Air Temperature in Rome. Urban Ecosystem, 9, 27-37. https://doi.org/10.1007/s11252-006-5527-2

[23] Peper, P.J., McPherson, E.G., Simpson, J.R., Gardner, S.L., Vargas, K.E. and Xiao, Q. (2007) New York City, New York Municipal Forest Resource Analysis. Center for Urban Forest Research, USDA Forest Service, Pacific Southwest Research Station, Davis.

[24] Lehmann, S. (2013) Low-to-No Carbon City: Lessons from Western Urban Projects for the Rapid Transformation of Shanghai. Habitat International, 37, 61-69. https://doi.org/10.1016/j.habitatint.2011.12.014

[25] Weigelt, A., Marquard, E., Temperton, V.M., Roscher, C., Scherber, C., Mwangi, P., Von Felten, S., Buchmann, N., Schmid, B., Schulze, E.-D. and Weisser, W.W. (2010) The Jena Experiment: Six Years of Data from a Grassland Biodiversity Experiment. Ecology, 91, 930-931. https://doi.org/10.1890/09-0863.1

[26] Gratani, L., Crescente, M.F., Varone, L., Fabrini, G. and Digiulio, E. (2008) Growth Pattern and Photosynthetic Activity of Different Bamboo Species Growing in the Botanical Garden of Rome. Flora, 203, 77-84.

https://doi.org/10.1016/j.flora.2007.11.002

[27] Brodribb, T.J. and Field, T.S. (2010) Leaf Hydraulic Evolution Led a Surge in Leaf Photosynthetic Capacity during Early Angiosperm Diversification. Ecology Letters, 13, 175-183. https://doi.org/10.1111/j.1461-0248.2009.01410.x 